\title{
Characterization of some Vitis vinifera L. Indigenous Varieties by Analysis of Leaf Photosynthetic Pigments
}

\author{
Vasile Răzvan FILIMON ${ }^{1 *}$, Roxana FILIMON ${ }^{1)}$, Liliana ROTARU ${ }^{1)}$ \\ 1) University of Agricultural Sciences and Veterinary Medicine „Ion Ionescu de la Brad” 3, Mihail Sa- \\ doveanu Alley, 700490, Iași, Romania. \\ ${ }^{*}$ Coresponding author, e-mail: razvan_f80@yahoo.com
}

Bulletin UASVM Horticulture 71(2) / 2014

Print ISSN 1843-5254, Electronic ISSN 1843-5394

DOI:10.15835/buasvmcn-hort:10278

\begin{abstract}
Chlorophyll content in leaves of 11 Vitis vinifera L. indigenous varieties (Iasi vineyard, Romania) was determined by two independent methods: spectrophotometry (extraction) and with a OptiSciences CCM-200 plus chlorophyll content meter (non-destructive method) with the aim of comparing the results. Also, this study was conducted to establish the values of chlorophyll $a$ / chlorophyll $b$ and chlorophyll/carotenoid ratio in middle leaves of vine stocks, in the phenophase of progressive growing of shoots. Area and perimeter of leaves in this phenophase were determined. Total chlorophyll concentration in leaf extract varied from $0.67 \pm 0.01 \mathrm{mg} / \mathrm{g}$ f.w. to $1.00 \pm 0.03 \mathrm{mg} /$ g f.w., being highly correlated with the chlorophyll content index values (CCI) recorded by CCM-200 $\left(\mathrm{R}^{2}=0.9839 ; \mathrm{p}<0.001\right)$. Similar situation was identified in the case of the chlorophyll $b$ and CCI correlation $\left(\mathrm{R}^{2}=0.9638 ; \mathrm{p}<0.001\right)$. Chlorophyll $a / b$ ratio in leaf extract varied significantly depending on variety, ranging from $1.06 \pm 0.01$ to $2.43 \pm 0.01$, with a chlorophyll/carotenoid ratio reaching up to $3.19 \pm 0.08$. Compared to spectrophotometry, CCM-200 plus affords fast, reliable, economical, non-destructive chlorophyll content measurement, however, providing no details regarding chlorophyll components and ratios.
\end{abstract}

Keywords: chlorophyll content meter, chlorophyll $a / b$ ratio, chlorophyll/carotenoid ratio, spectrophotometry, Vitis vinifera L.

\section{INTRODUCTION}

First isolated by Caventou and Pelletier in 1817, chlorophyll (gr. chloros - green; phyllon leaf) is a biomolecule critical in photosynthesis (gr. photos - light; synthesis - building a whole), which allow plants to absorb energy from light (Davies, 2004). Chlorophyll $a$ and chlorophyll $b$ are the major types of chlorophylls found in plants (Wilows, 2004). They have a characteristic green colour due to strong absorbance of blue and red light. The increased proportion of chlorophyll $b$ is due to its absorption in the 450$480 \mathrm{~nm}$ range, capturing effectively light at low intensity (Lichtenthaler and Wellburn, 1983). The chlorophyll $a / b$ ratio varies from $2.0-3.2$ for shade adapted plants to 3.5-4.9 for plants adapted to sunny conditions (Lichtenthaler et al., 1982). In $V$. vinifera L. leaves chlorophyll $a / b$ ratio is maximum at the beginning of the vegetation period, reaching $3 / 1$ and decreases during grape maturation, while the chlorophyll/carotenoids ratio may reach up to 4/1(Keller, 2010; Toma and Jităreanu, 2007). Variation of chlorophyll $a / b$ and chlorophyll/carotenoids ratio can be an indicator of senescence, stress, and damage to the photosynthetic apparatus, but can also provide distinctive informations on plant phenophase. Modification of chlorophyll $a$ /chlorophyll $b$ ratio is determined mainly by the decrease of chlorophyll $a$ concentration during leaf vegetation (Burzo et al., 2005). 
Carotenoids are a large group of deeply red or yellow fat-soluble pigments (Pfander, 1992). Carotenoids are found in all photosynthetic organisms, beeing involved in photosystem assembly and contribute to light harvesting by absorbing light energy in a region of the visible spectrum where chlorophyll absorption is lower and by transferring the energy to chlorophyll. Also, carotenoids provide protection from excess light, free radical detoxification and limiting damage to membranes (Cuttriss and Pogson, 2004).

Determinations carried out on $V$. vinifera $\mathrm{L}$. varieties showed that carotenoid concentration in leaves varied from $7.72 \mathrm{mg} / 100 \mathrm{~g}$ to 17.26 $\mathrm{mg} / 100 \mathrm{~g}$ f.w., with a gradual accumulation during leaf maturation (Burzo et al., 2005; Mendes-Pinto et al., 2005).

The Opti-Sciences CCM-200 plus chlorophyll content meter is an instrument which provides fast and accurate chlorophyll content index (CCI) readings on the intact leaves of plants, without the need for destructive chlorophyll assays. The measurement is rapid and simple to obtain compared to chlorophyll extraction and spectrophotometric reading (Biber, 2007). Previous research conducted on different species showed significantly linear correlation of total chlorophyll (by spectrophotometry) and CCI values (by chlorophyll content meters), however with large differences in terms of data correlation (Callejas et al., 2013; Ghasemi et al., 2011; Khaleghi et al., 2012; Richardson et al., 2002; Schaper and Chacko, 1991; van den Berg and Perkins, 2004). Currently, the lack of a more consistent relationship between chlorophyll concentrations estimated by the extraction method and by the chlorophyll meter at $V$. vinifera $L$. for different genotypes and at different growth stages, limits the potential use of CCM-200 plus for this species.

\section{MATERIALS AND METHODS}

The research has been carried out on the young leaves of 11 Vitis vinifera L. indigenous varieties (Gelu, Milcov, Cetățuia, Napoca, Someșan, Splendid, Transilvania, Coarnă neagră, Coarnă neagră selecționată, Purpuriu and Radames), growing in the Ampelographic Collection of the University of Agricultural Sciences and Veterinary Medicine Iasi, Romania, in the phenophase of progressive growing of shoots (20 days after bud burst). Grapevines varieties were 25 years old grafted on Kober 5 BB (Berlandieri $\times$ Riparia). Planting distances were $2.2 \mathrm{~m}$ (between rows) $/ 1.2$ $\mathrm{m}$ (between plants), half-high training system, bilateral cordon, with pruning in fructification rings providing an average load of 40-45 buds/ vine. Soil maintenance was "black field" and technological operations were specific to industrial vineyard ecosystem.

Designed to non-destructively measure of chlorophyll concentration in leaf tissue without the need to detach and grind a sample, Opti-Sciences CCM-200 plus exploits that total chlorophyll has several distinct optical absorbance characteristics, in order to determine relative chlorophyll concentration. Chlorophyll content index (CCI) represents the ratio between transmittance at 931 $\mathrm{nm}$ and transmittance at $653 \mathrm{~nm}$. One wavelength falls within the chlorophyll absorbance range while the other serves to compensate for mechanical differences such as tissue thickness. Calibration is required every time is started a new experiment (Gandia et al., 2004). The Opti-Sciences CCM200 chlorophyll content index (CCI) values were registered simultaneously, on the same leaves considered for extraction.

Leaf samples (5) for extraction were harvested manually, in the morning, from the middle third of vine shoots, rapidly frozen (in 10 minutes) and analyzed in same day. Frozen leaf samples $(0.5 \mathrm{~g})$ were ground in a mortar using sieved inert sand as a grinding aid. Solvent of $99.98 \%$ acetone $(10 \mathrm{~mL})$ was used to extract the photosynthetic pigments from the leaf tissue. The extract was placed in the refrigerator overnight to minimize phototransformation of chlorophyll and to complete extraction (Biber, 2007). Small amount of $\mathrm{MgCO}_{3}(0.5 \mathrm{mg})$ was added during extraction to neutralize plant acids responsable for the formation of pheophytin $a$ from chlorophyll $a$ (Lee and Schwartz, 2005). Supernatant was transferred into $1 \mathrm{~cm}$ path length quartz cuvettes. The analytical determination was conducted using a UV-vis Shimadzu 1700 Pharmaspec Spectrophotometer at the following wavelengths: 662 and $645 \mathrm{~nm}$, for chlorophyll $a$ and $b$ and $470 \mathrm{~nm}$ for carotenoids (xanthophylls and carotenes) as part of a full scan of the sample (400-800 nm). Turbidity (haze) can be checked by measuring absorbance (A) at $710 \mathrm{~nm}$. For a fully transparent leaf pigment extract, A710-750 $\mathrm{nm}$ should equal zero, since chlorophylls $a$ (Chl 
$a$ ) and $b(\mathrm{Chl} b)$ and carotenoids do not absorb in this region (Lichtenthaler and Buschmann, 2001; Spectranomics Protocol, 2011). Photosynthetic pigment content was calculated in $\mathrm{mg} / \mathrm{g}$ fresh weight (f.w.) to allow comparison among species, using the three "trichromatic" equations sugested by Lichtenhaler (1987) and Lichtenthaler and Buschmann (2001) and improved by Carnegie Institution for Science through Spectranomics Protocol, 2011:

Chl $a\left(\mu \mathrm{g} \mathrm{mL}^{-1}\right)=11.24 \times\left(\mathrm{A}_{662}-\mathrm{A}_{710}\right)-2.04 \times$ $\left(\mathrm{A}_{645}-\mathrm{A}_{710}\right)$;

$\operatorname{Chl} b\left(\mu \mathrm{g} \mathrm{mL} \mathrm{L}^{-1}\right)=20.13 \times\left(\mathrm{A}_{645}-\mathrm{A}_{710}\right)-4.19 \times$ $\left(\mathrm{A}_{662}-\mathrm{A}_{710}\right)$;

Carotenoids $\left(\mu \mathrm{g} \mathrm{mL}^{-1}\right)=\left(1000 \times\left(\mathrm{A}_{470}-\mathrm{A}_{710}\right)-1.90\right.$ $\times$ Chl $a-63.14 \times \mathrm{Chl} b) / 214$.

Area, length, width and perimeter of the leaf was measured (by scanning) with a portable ADC BioScientific AM 300 Area meter (non-destructive method).

A one-way Analysis of variance (ANOVA) test was initiated to investigate significant differences between methods. The method used to discriminate among the means was Fischer's least significant difference procedure at 95\% confidence level. Simple regression analysis was performed to look for relationships between data registered by two independent methods. P values lower than $0.05(\mathrm{p}<0.05)$ were considered to be significant.

Statistical measure of the dispersion of data points around the mean was conducted using the coefficient of variation (CV), which represents the ratio of the standard deviation (St. dev.) to the mean (\%).

\section{RESULTS AND DISCUSSIONS}

Determination of moisture is an essential step in vegetal tissue analysis, high proportion of water causing a poor stability of samples, favoring microbiological and enzymatic activity, and hydrolysis reactions (Beceanu et al., 2011; Maltini et al., 2003). In a typical grapevine leaf water content depends on the physiological condition, age and intensity of plant metabolism, ranging from 70 to 85\% (Boyer et al., 1997; Mustea, 2004). In studied romanian varieties leaves moisture content was high, specific to the phenophase (shoot growing), and varying from $76.32 \%$ to $81.43 \%$, with a mean of $78.61 \%$ (Tab. 1 ).

Total dry matter of leaves (\%), represented by all their constituents excluding water, is naturally correlated with the moisture content of samples.

According to the absorbance spectra in the 400-800 $\mathrm{nm}$ range (Fig. 1), was calculated the amount of chlorophyll $(a$ and $b$ ) and total carotenoids in leaf extracts.

Tab. 1. Moisture and dry matter content (\%) in leaves of indigenous V. vinifera varieties

\begin{tabular}{|c|c|c|c|c|}
\hline Variety & $\begin{array}{c}\text { Moisture } \\
(\%)\end{array}$ & $\begin{array}{c}\text { St. } \\
\text { dev. }\end{array}$ & $\begin{array}{c}\text { Total dry matter } \\
(\%)\end{array}$ & $\begin{array}{l}\text { St. } \\
\text { dev. }\end{array}$ \\
\hline Cetățuia & $76.32^{000}$ & 1.50 & $23.68^{n+*}$ & 1.50 \\
\hline Someșan & $76.45^{\circ 0}$ & 1.21 & $23.55^{* *}$ & 1.21 \\
\hline Coarnă neagră & $77.75^{\mathrm{Ns}}$ & 0.89 & $22.25^{\mathrm{ss}}$ & 0.89 \\
\hline Coarnă neagră selecționată & $77.88^{\mathrm{ss}}$ & 1.54 & $22.12^{\mathrm{Ns}}$ & 1.54 \\
\hline Radames & $78.03^{\text {vs }}$ & 0.90 & 21.97 ss & 0.90 \\
\hline Napoca & $78.05^{\mathrm{Ns}}$ & 1.02 & $21.95^{\mathrm{Ns}}$ & 1.02 \\
\hline Milcov & $78.98^{\mathrm{ss}}$ & 1.10 & $21.02^{\mathrm{Ns}}$ & 1.10 \\
\hline Purpuriu & $79.59^{\text {Ns }}$ & 1.80 & $20.41^{\mathrm{Ns}}$ & 1.80 \\
\hline Splendid & $80.03^{\text {ss }}$ & 1.65 & $19.97^{\mathrm{Ns}}$ & 1.65 \\
\hline Transilvania & $80.18^{\text {vs }}$ & 0.94 & $19.82^{\mathrm{Ns}}$ & 0.94 \\
\hline Gelu & $81.43^{\cdots+*}$ & 1.12 & 18.57000 & 1.12 \\
\hline Mean & 78.61 & 1.59 & 21.39 & 1.59 \\
\hline CV\% & 2.02 & - & 7.4 & - \\
\hline
\end{tabular}

Note: Data expressed as mean values with standard deviation $(\mathrm{n}=3) .{ }^{\mathrm{Ns}, * * *, * * *}$ - indicate nonsignificant and positive significant at $p \leq 0.05,0.01$, 0.001 , respectively; ${ }^{\circ, \text { oo, ooo }}$ - negative significant at $p \leq 0.05,0.01,0.001$. 
Previous research reported that new leaves usually have a low photosynthetic activity, concentration of assimilatory pigments reaching maximum values in leaves at the age of 20-30 days, furthermore, with a continuous accumulation until grape veraison (Burzo et al., 2005; Keller, 2010; Lovisolo et al., 1996). Chlorophyll $a$, chlorophyll $b$ and carotenoid concentration in fresh young leaves of romanian $V$. vinifera L. varieties studied is shown in Tab. 2, as mean values with standard deviation (significant differences to the mean are noted).

Concentration of chlorophyll $a$ in extracts presented small variation between varieties, with a negative statistical significance $(\mathrm{p}<0.05)$ in the case of Purpuriu variety $(0.47 \pm 0.01 \mathrm{mg} / \mathrm{g}$ f.w. $)$.

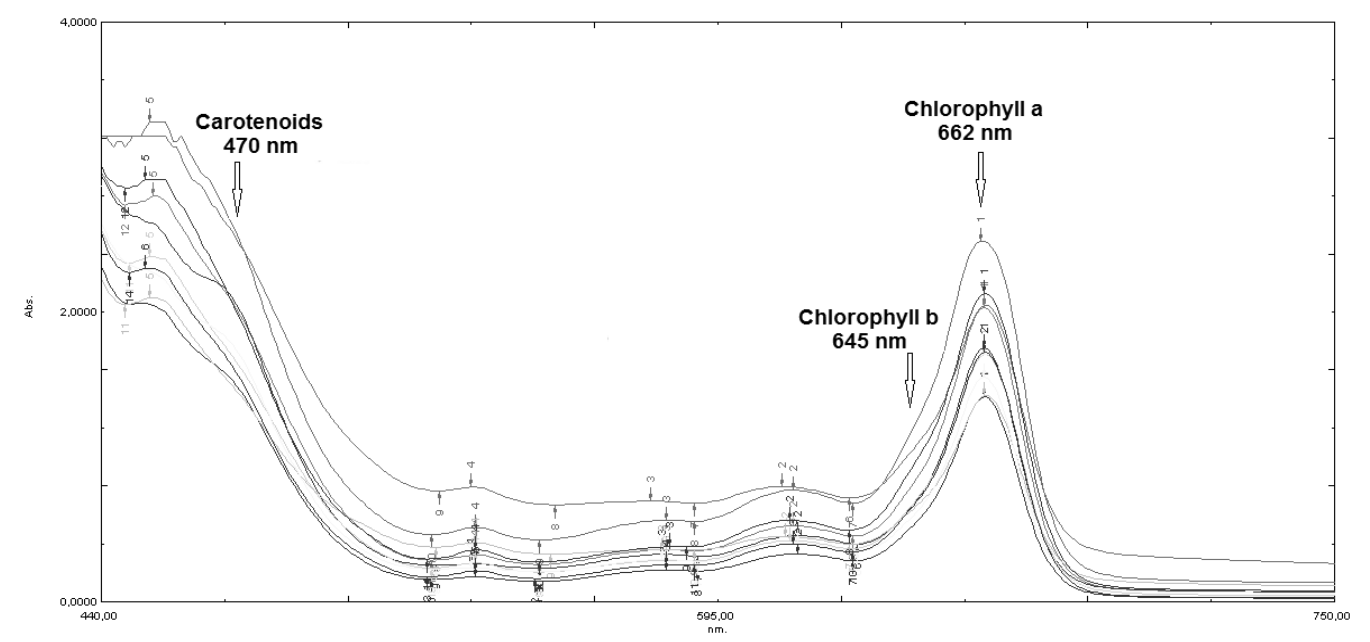

Fig. 1. Absorption spectra of leaf extracts of $V$. vinifera L. indigenous varieties

Tab. 2. The content of chlorophyll $a$, chlorophyll $b$ and carotenoids (mg/g f.w.) and ratios between them in leaves of indigenous $V$. vinifera L. varieties

\begin{tabular}{|c|c|c|c|c|c|c|c|c|c|c|c|c|}
\hline Variety & $\begin{array}{c}\text { Chl } \\
a\end{array}$ & $\begin{array}{c}\text { St. } \\
\text { dev. }\end{array}$ & $\begin{array}{c}\text { Chl } \\
b\end{array}$ & $\begin{array}{l}\text { St. } \\
\text { dev. }\end{array}$ & $\begin{array}{c}\text { Carote- } \\
\text { noids }\end{array}$ & $\begin{array}{l}\text { St. } \\
\text { dev. }\end{array}$ & $\begin{array}{c}\text { Total } \\
\text { Chl }\end{array}$ & $\begin{array}{l}\text { St. } \\
\text { dev. }\end{array}$ & $\begin{array}{c}\text { Chl } \\
a / \\
\text { Chl } b\end{array}$ & $\begin{array}{l}\text { St. } \\
\text { dev. }\end{array}$ & $\begin{array}{c}\text { Chl/ } \\
\text { Caroten. }\end{array}$ & $\begin{array}{l}\text { St. } \\
\text { dev. }\end{array}$ \\
\hline Cetățuia & $0.52^{\text {Ns }}$ & 0.02 & $0.37^{\mathrm{Ns}}$ & 0.02 & $0.31^{\mathrm{Ns}}$ & 0.01 & $0.89^{\text {Ns }}$ & 0.96 & $1.43^{\mathrm{ss}}$ & 0.01 & 2.87 ss & 0.04 \\
\hline Coarnă neagră & $0.52^{\mathrm{Ns}}$ & 0.01 & $0.41^{\mathrm{Ns}}$ & 0.01 & $0.33^{\mathrm{ss}}$ & 0.02 & $0.93^{\text {ss }}$ & 1.00 & $1.27^{000}$ & 0.02 & 2.87 s & 0.07 \\
\hline $\begin{array}{l}\text { Coarnă neagră } \\
\text { selecționată }\end{array}$ & $0.51^{\mathrm{Ns}}$ & 0.03 & $0.40^{\mathrm{Ns}}$ & 0.01 & $0.32^{\mathrm{Ns}}$ & 0.01 & $0.91^{\mathrm{Ns}}$ & 0.89 & $1.29^{000}$ & 0.01 & 2.87 ss & 0.07 \\
\hline Gelu & $0.52^{\mathrm{Ns}}$ & 0.02 & $0.43^{\mathrm{Ns}}$ & 0.01 & $0.31^{\mathrm{Ns}}$ & 0.01 & $0.95^{* *+*}$ & 0.96 & $1.21^{000}$ & 0.02 & $3.04^{* * *}$ & 0.01 \\
\hline Milcov & $0.52^{\text {Ns }}$ & 0.01 & $0.49^{* * *}$ & 0.03 & $0.32^{\mathrm{Ns}}$ & 0.01 & $1.01^{* * *}$ & 0.67 & $1.06^{000}$ & 0.01 & $3.19^{* * *}$ & 0.08 \\
\hline Napoca & $0.52^{\text {Ns }}$ & 0.02 & $0.44^{\mathrm{Ns}}$ & 0.02 & $0.32^{\mathrm{Ns}}$ & 0.02 & $0.96^{* * *}$ & 0.88 & $1.18^{000}$ & 0.01 & $2.97^{* *}$ & 0.07 \\
\hline Purpuriu & $0.47^{\circ}$ & 0.01 & $0.20^{000}$ & 0.01 & $0.28^{\mathrm{Ns}}$ & 0.01 & $0.67^{000}$ & 0.92 & $2.43^{\cdots}$ & 0.03 & $2.42^{000}$ & 0.02 \\
\hline Radames & $0.51^{\text {ss }}$ & 0.03 & $0.37_{\mathrm{Ns}}$ & 0.01 & $0.29^{\mathrm{Ns}}$ & 0.01 & $0.88^{\mathrm{Ns}}$ & 0.87 & $1.39^{\mathrm{Ns}}$ & 0.02 & $3.02^{* * *}$ & 0.03 \\
\hline Someșan & $0.52^{\text {Ns }}$ & 0.01 & $0.40^{\mathrm{Ns}}$ & 0.01 & $0.32^{\mathrm{Ns}}$ & 0.01 & $0.92^{\text {Ns }}$ & 0.94 & $1.33^{000}$ & 0.01 & $2.84^{\circ 0}$ & 0.07 \\
\hline Splendid & $0.53^{\text {s }}$ & 0.01 & $0.35^{\mathrm{Ns}}$ & 0.02 & $0.31^{\mathrm{Ns}}$ & 0.02 & $0.88^{\mathrm{Ns}}$ & 0.91 & $1.52^{* * *}$ & 0.03 & $2.79_{000}$ & 0.04 \\
\hline Transilvania & $0.52^{\text {Ns }}$ & 0.02 & $0.40^{\mathrm{Ns}}$ & 0.01 & $0.32^{\mathrm{Ns}}$ & 0.01 & $0.92^{\text {Ns }}$ & 0.92 & $1.29^{000}$ & 0.01 & $2.91^{\mathrm{Ns}}$ & 0.07 \\
\hline Mean & 0.52 & 0.02 & 0.39 & 0.07 & 0.31 & 0.01 & 0.90 & 0.09 & 1.40 & 0.36 & 2.89 & 0.19 \\
\hline CV\% & 3.92 & - & 17.95 & - & 3.22 & - & 10.00 & - & 25.71 & - & 6.57 & - \\
\hline
\end{tabular}

Note: Data expressed as mean values with standard deviation $(\mathrm{n}=3) .{ }^{\mathrm{Ns},{ }^{* *+*}, *+*}$ - indicate nonsignificant and positive significant at $p \leq 0.05,0.01$, 0.001 , respectively; ${ }^{0,00,000}$ - negative significant at $p \leq 0.05,0.01,0.001$. 
Chlorophyll $b$ content of young V. vinifera L. leaves varied widely compared to chlorophyll $a$, with a high value of coefficient of variability between data $(\mathrm{CV}=17.95 \%)$, and reaching a maximum of $0.49 \pm 0.03 \mathrm{mg} / \mathrm{g}$ f.w. at Milcov variety.

Chlorophyll $a / b$ ratio was specific to each variety, and varied within the range of $1.06 \pm 0.01$ (Milcov variety) to $2.43 \pm 0.03$ (Purpuriu variety), with a mean of $1.40 \pm 0.36$.

According to Gross (1991) and Wilows (2004), in mature leaves chlorophyll $a$ is the major pigment and chlorophyll $b$ is accessory pigment which exist in a ratio of approximately 3 to 1 . It has been generally reported that chlorophyll $a / b$ ratio of leaves is maximum at the beginning of vegetation period (Lichtenthaler et al., 1981; Toma and Jităreanu, 2007). Chlorophyll $a / b$ ratio in leaves of romanian grapevine varieties studied in the phenophase of progressive growing of shoots had lower values than those presented in international literature, but comparable to data presented by researchers from Romania, from 1.3 to 1.4 (Acatrinei and Andor, 2006; Coţovanu et al., 2012). Thereby, lower values of chlorophyll $a / b$ ratio could be a peculiarity of romanian indigenous vine varieties, especially for those growing in N-E of the country, an areal with continental climate characterized by alternating hot and cold days, with frequent moisture deficit especially to the hills, that can frequently cause blockages of photosynthesis processes (Teodorescu et al., 1987; Cotea et al., 2000). On the other hand, according to Hopkins and Hüner (2009), typically photosystem (PS) 1 has a chlorophyll $a / b$ ratio of about $4 / 1$, and PS 2 contains 50 to $60 \%$ of the total chlorophyll, with a chlorophyll $a / b$ ratio of about 1.2 , most of the chlorophyll $b$ and carotenoids (xanthophyll). These data along with those reported by Jiang et al. (2005) and Jiang et al. (2006), which shows that the probability for energy transfer among PS 2 units in newly initiating vine leaves was distinctly higher than in mature ones and that only a few functional PS 1 were developed at the initial stages of leaf growth, could also explain the low values of the chlorophyll $a / b$ ratio in young leaves of analysed varieties.

Burzo et al. (2005) reported that the carotenoid content of grapevine leaves has a specific accumulation, with lower values at the beginning of vegetation period. Carotenoid pigments (carotenes and xanthophylls) were present in lower concentration in grapevine young leaves compared to chlorophylls, without exceeding $0.33 \pm 0.01 \mathrm{mg} / \mathrm{g}$ f.w., with a proper chlorophyll/carotenoid ratio of $2.42 \pm 0.02-3.19 \pm 0.08$ (Tab. 2). These values are within the published range for $V$. vinifera $L$. leaves presented by Burzo et al. (2005), but are slightly lower than those reported by Young and Britton (1993) and Bertamini and Nedunchezhian (2003), where chlorophyll/carotenoid ratio was in the range of 3 to 4 .

Chlorophyll content index (CCI) in leaves of $V$. vinifera $\mathrm{L}$. varieties, determined by means of hand held CCM-200 plus, ranged from $4.10 \pm 0.19$ to $6.26 \pm 0.17$ (Tab. 3).

Tab. 3. Chlorophyll content index (CCI) in leaves of indigenous V. vinifera L. varieties analysed

\begin{tabular}{|c|c|c|c|c|}
\hline Variety & Minimum & Maximum & Mean & St. dev. \\
\hline Purpuriu & 3.90 & 4.40 & $4.10^{000}$ & 0.19 \\
\hline Splendid & 4.20 & 5.70 & $5.20^{\mathrm{Ns}}$ & 0.59 \\
\hline Radames & 5.20 & 5.80 & $5.54^{\mathrm{Ns}}$ & 0.26 \\
\hline Cetățuia & 5.40 & 5.90 & $5.60^{\mathrm{Ns}}$ & 0.23 \\
\hline Coarnă neagră selecționată & 5.20 & 6.40 & $5.64^{\mathrm{Ns}}$ & 0.48 \\
\hline Transilvania & 5.40 & 5.80 & $5.66^{\mathrm{Ns}}$ & 0.24 \\
\hline Someșan & 5.60 & 5.80 & $5.76^{\mathrm{Ns}}$ & 0.21 \\
\hline Napoca & 5.80 & 6.10 & $5.92^{\mathrm{Ns}}$ & 0.13 \\
\hline Coarnă neagră & 5.50 & 6.20 & $5.98^{\mathrm{Ns}}$ & 0.29 \\
\hline Gelu & 5.40 & 6.10 & $6.00^{\mathrm{Ns}}$ & 0.60 \\
\hline Milcov & 5.40 & 6.40 & $6.26^{* *}$ & 0.17 \\
\hline Mean & 5.18 & 5.87 & 5.61 & 0.31 \\
\hline CV\% & 11.35 & 9.30 & 10.23 & - \\
\hline
\end{tabular}

Note: Data expressed as mean values with standard deviation $(\mathrm{n}=5) .{ }^{\mathrm{NS},{ }^{*}, * * * * *}$ - indicate nonsignificant and positive significant at $p \leq 0.05,0.01$, 0.001 , respectively; ${ }^{\circ, 00,000}$ - negative significant at $p \leq 0.05,0.01,0.001$. 


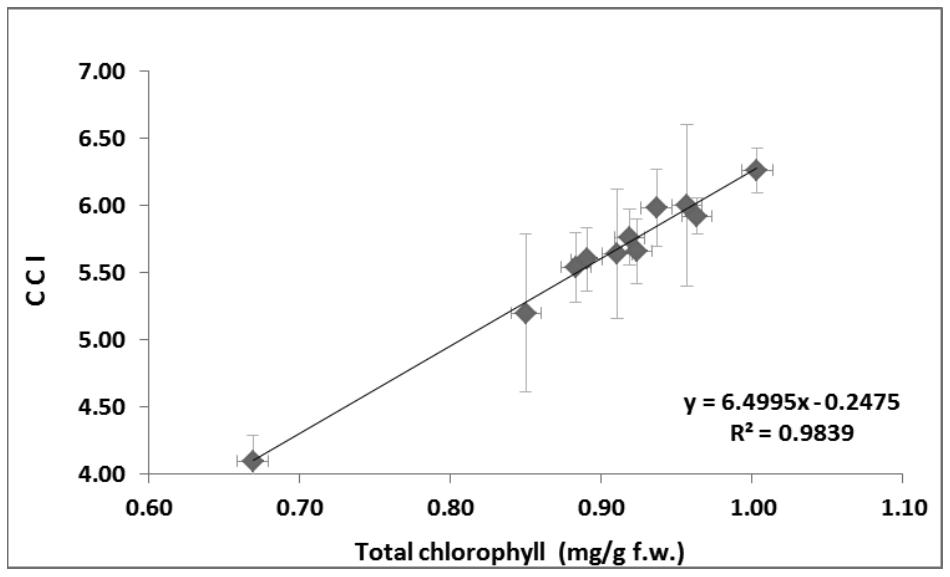

Fig. 2. Correlation of total chlorophyll and CCI values in leaves of V. vinifera $\mathrm{L}$. indigenous varieties in the phenophase of progressive shoot growing
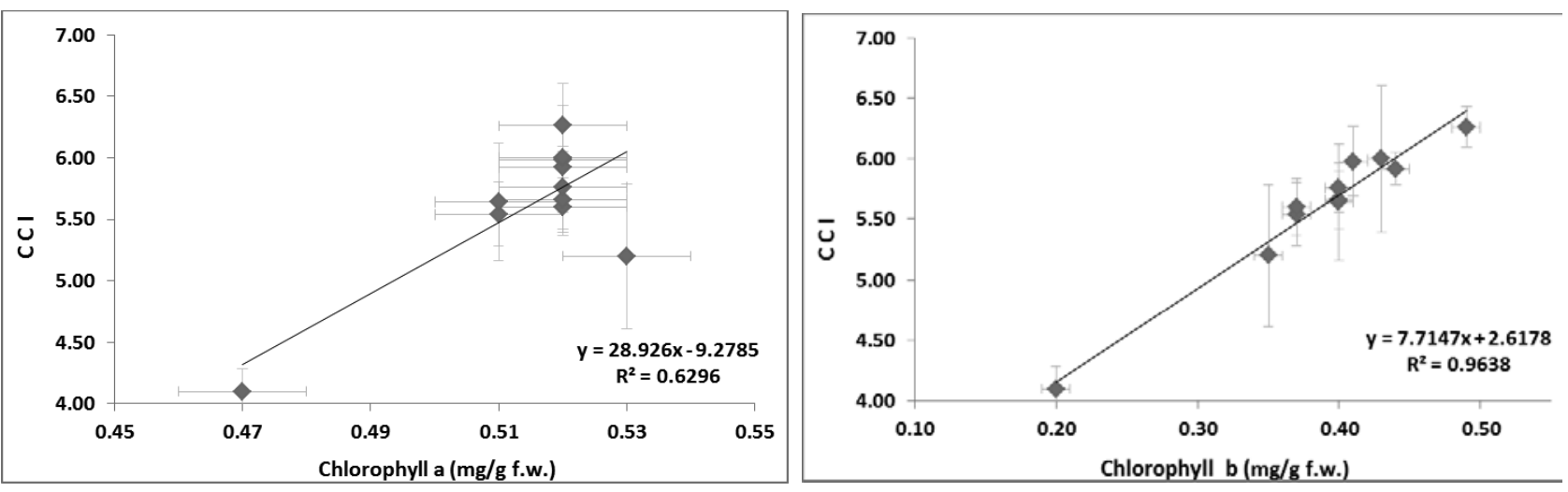

Fig. 3. Correlation of chlorophyll $a$ and chlorophyll $b$ with CCI values in leaves of $V$. vinifera L. indigenous varieties in the phenophase of progressive shoot growing

According to Van den Berg and Perkins (2004) and Yamamoto et al. (2002) small differences in the structures of the two main chlorophylls produce differences in the absorption maxima of chlorophyll $a$ and chlorophyll $b$, which helps in their individual analysis. This fact can be exploited spectrophotometrically (by extraction), but not by a chlorophyll content meter.

The relationship between total extractable chlorophyll $(a+b)$ and CCI values was significantly linear, with $\mathrm{R}^{2}$ indicating that $98 \%(\mathrm{p}<0.001)$ of the variation was explained by a linear model, with conversion equation: $y=6.4995 x-0.2475$ (Fig. 2).

Chlorophyll $a$ and CCI values correlation in young leaves of $V$. vinifera $\mathrm{L}$. romanian varieties resulting in a weak relationship $\left(\mathrm{R}^{2}=0.6296\right)$, while chlorophyll $b$ and CCI values was significantly linear, similar to total chlorophyll content, with $\mathrm{R}^{2}$ indicating that $96 \%$ $(\mathrm{p}<0.001)$ of the variation was explained by the model obtained (Fig. 3).

However, for most CCI values, it appears that the chlorophyll meter CCM-200 plus is able to provide a relative estimate of total chlorophyll in grapevine leaves based on a linear model, at least for the phenological phase under study.

Variety influences photosynthesis process through both photosynthetic pigment content and leaf morphological particularities. The elements that compose the leaf structure (e.g. thickness of mesophyll), and leaf shape and area have an important role in the process of photosynthesis and are specific to each variety (Lebon et al., 2005). Also, technological factors such as training system, type of pruning, number of buds, rootstock used, along with fertilization, irrigation, soil tillage, attack of diseases and pests, affect the accumulation of photosynthetic pigments and 
certainly their determination (Keller, 2010; Rotaru et al., 2011).

In order to determine whether the chlorophyll and carotenoid content of leaves is influenced by their biometric characteristics, leaf size and shape (area and perimeter) were determinated by an AM-300 portable instrument (Tab. 4). Measurements are made optically using a simple scanning process. Both measurements and the scanned shape were stored and transferred to a personal computer.

Leaves selected for the measurements were collected from the middle of the vine stock (the middle third of shoots), where, according to Rotaru and Ţârdea (2002), the variability of ampelo- graphic characters is the most reduced. Generally, leaves from the base and the top of shoots have a lower content of assimilatory pigments and a lower photosynthetic activity, leaves between nodes 5-10 being the most photosynthetically active (Mustea, 2004).

Leaf area ranged from $2907 \pm 56 \mathrm{~mm}$ (Transilvania variety) to $6792 \pm 125 \mathrm{~mm}$ (Coarnă neagră selecţionată variety), with a mean of $5210 \mathrm{~mm}$ and a standard deviation between varieties of $1157 \mathrm{~mm}$. A high value of coefficient of variability between data was calculated in the analysis of leaf perimeter $(\mathrm{CV}=31.7 \%)$, as a result of an high variability between varieties in respect to this parameter.

Tab. 4. Area and shape of leaves of indigenous V. vinifera L. varieties in the phenophase of shoot growing

\begin{tabular}{|c|c|c|c|c|c|c|c|c|c|}
\hline Variety & $\begin{array}{l}\text { Area } \\
(\mathrm{mm})\end{array}$ & $\begin{array}{l}\text { St. } \\
\text { dev. }\end{array}$ & $\begin{array}{l}\text { Length } \\
(\mathrm{mm})\end{array}$ & $\begin{array}{l}\text { St. } \\
\text { dev. }\end{array}$ & $\begin{array}{l}\text { Width } \\
\text { (mm) }\end{array}$ & $\begin{array}{l}\text { St. } \\
\text { dev. }\end{array}$ & $\begin{array}{l}\text { Perimeter } \\
(\mathrm{mm})\end{array}$ & $\begin{array}{c}\text { St. } \\
\text { dev. }\end{array}$ & Scanned image \\
\hline Cetățuia & $3903^{000}$ & 64 & $71.6^{000}$ & 8.9 & $77.5^{\mathrm{Ns}}$ & 6.8 & $528.7^{\circ 0}$ & 28.1 & \\
\hline Coarnă neagră & $6401^{* * *}$ & 101 & $95.5^{*}$ & 12.5 & $95.0^{\mathrm{Ns}}$ & 4.9 & $684.2^{* * *}$ & 14.3 & \\
\hline $\begin{array}{l}\text { Coarnă neagră } \\
\text { selecţionată }\end{array}$ & $6792^{* * *}$ & 125 & $103.1^{m+*}$ & 14.8 & $94.7^{\mathrm{Ns}}$ & 10.4 & $527.3^{\circ 0}$ & 15.1 & \\
\hline Gelu & $5885^{* * *}$ & 124 & 94.2 & 9.4 & $88.1^{\mathrm{Ns}}$ & 11.2 & $516.4^{\circ 0}$ & 18.9 & \\
\hline Milcov & $5714^{*+*}$ & 59 & $95.0^{*}$ & 8.7 & $90.2^{\mathrm{Ns}}$ & 8.6 & $597.1^{* *}$ & 10.4 & \\
\hline Napoca & $4864^{000}$ & 102 & $87.6^{\mathrm{Ns}}$ & 11.4 & $83.8^{\mathrm{Ns}}$ & 7.4 & $402.1^{1000}$ & 19.2 & \\
\hline Purpuriu & $4196^{000}$ & 96 & $83.1^{\circ 0}$ & 11.6 & $86.1^{\mathrm{Ns}}$ & 10.8 & $594.3^{\mathrm{Ns}}$ & 20.7 & \\
\hline Radames & $5237^{\text {ss }}$ & 147 & $92.7^{\mathrm{ss}}$ & 10.4 & $87.1^{\mathrm{Ns}}$ & 10.2 & $486.3^{000}$ & 16.1 & \\
\hline Someşan & $5465^{* * *}$ & 88 & $91.7^{\mathrm{ss}}$ & 9.4 & $84.6^{\mathrm{Ns}}$ & 6.5 & $1018.6^{n+*}$ & 11.1 & \\
\hline Splendid & $5943^{*+* *}$ & 197 & $100.1^{* * *}$ & 8.2 & $87.9^{\mathrm{ss}}$ & 9.3 & $670.5^{* * *}$ & 12.4 & \\
\hline Transilvania & 2907000 & 56 & $72.9^{000}$ & 11.0 & $62.7^{000}$ & 7.4 & $310.8^{000}$ & 10.6 & \\
\hline Mean & 5210 & 1157 & 89.8 & 10.2 & 85.2 & 8.9 & 576.0 & 182.8 & - \\
\hline CV\% & 22.2 & - & 11.3 & - & 10.4 & - & 31.7 & - & - \\
\hline
\end{tabular}

Note: Data expressed as mean values with standard deviation $(\mathrm{n}=3)^{\mathrm{NS},{ }^{*}, * * * * *}$ - indicate nonsignificant and positive significant at $p \leq 0.05,0.01$, 0.001 , respectively; ${ }^{\circ, \text { oo, oo }}$ - negative significant at $p \leq 0.05,0.01,0.001$. 
Tab. 5. Correlation of photosynthetic pigments concentration, CCI values and biometric data of leaves of indigenous $V$. vinifera L. varieties

\begin{tabular}{cccccccc}
\hline V. vinifera L. & Chl $a$ & Chl $b$ & $\begin{array}{c}\text { Total chl } \\
(a+b)\end{array}$ & Carotenoids & CCI & $\begin{array}{c}\text { Leaf } \\
\text { Area }\end{array}$ & $\begin{array}{c}\text { Leaf } \\
\text { perimeter }\end{array}$ \\
\hline Chl $a$ & 1 & & & & & & \\
\hline Chl $b$ & 0.7877 & 1 & & & & & \\
\hline Total chl $(a+b)$ & $\mathbf{0 . 8 5 2 2}$ & $\mathbf{0 . 9 9 3 6}$ & 1 & & & & \\
\hline Carotenoids & 0.7389 & 0.7786 & $\mathbf{0 . 7 9 6 6}$ & 1 & & & \\
\hline CCI & $\mathbf{0 . 7 9 3 4}$ & $\mathbf{0 . 9 8 1 7}$ & $\mathbf{0 . 9 7 9 1}$ & 0.7838 & 1 & & \\
\hline Leaf Area & 0.2304 & 0.3177 & 0.3120 & 0.2974 & 0.3220 & 1 & \\
\hline Leaf perimeter & 0.0493 & -0.0753 & -0.0549 & 0.1178 & -0.0299 & 0.4331 & 1 \\
\hline
\end{tabular}

Note: Bolded values suggests that correlation coefficients are statistically significant in ANOVA test $(p<0.05)$

Pearson's correlation (Data analisys, Microsoft Excel), between area and perimeter of leaves, extractable photosynthetic pigment content and CCI values, reported that there was no positive or negative relationship between experimental data (Tab. 5).

However, a linear relationship was noticed between chlorophyll $b$ and total chlorophyll with a correlation coefficient of $0.9936(\mathrm{p}<0.001)$, and was also confirmed the correlation between total chlorophyll content and CCI values ( $\mathrm{r}=0.9791$; $\mathrm{p}$ $<0.001$ ).

\section{CONCLUSION}

In young leaves of Vitis vinifera L. varieties native to Romania, concentration of photosynthetic pigments and the relationship between them was specific to each variety. Low chlorophyll $a / b$ ratio may be a peculiarity of indigenous grapevine varieties from Romania and can be attributed to the specific climatic conditions and/or to the phenophase considered (progressive growing of shoots). This relation shall be established in the further studies.

Carotenoid pigments were present in low concentration in grapevine leaves compared to chlorophylls, with a chlorophyll/carotenoids ratio that falls within the published range for this species, from 2.4 to 3.2 .

Compared to spectrophotometry (that require extraction of assimilatory pigments), OptiSciences CCM-200 plus chlorophyll content meter provide fast, reliable, economical measurement of chlorophyll concentration, but with no details regarding chlorophyll components and ratios.

The data in this study indicate that chlorophyll meter CCM-200 plus appears to be able to provide a relative estimation of extracted chlorophyll in Vitis vinifera L. young leaves based on a linear model (by an equation of conversion). Once this relationship is established, the CCM can become an effective tool in plant management (e.g. plant health status, assessment of physiological changes over time, or in treatments affecting plant growth and development).

Acknowledgments. This paper was published under the frame of European Social Fund, Human Resources Development Operational Programme 2007-2013,projectno.POSDRU/159/1.5/S/132765.

\section{REFERENCES}

1. Acatrinei L and Andor I (2006). Physiological researches at varieties of grapes in Cotnari vineyards under pesticides treatments. Scientific Papers U.A.S.V.M. Iași, Serie Horticulture. 49(1): 317-322.

2. Bartley GE and Scolnik PA (1995). Plant carotenoids: pigments for photoprotection, visual attraction, and human health. The Plant Cell. 7: 1027-1038.

3. Bertamini M and Nedunchezhian N (2003). Photosynthetic functioning of individual grapevine leaves (Vitis vinifera L. cv. Pinot noir) during ontogeny in the field. Vitis. 42(1): 13-17.

4. Beceanu D, Anghel R and Filimon VR (2011). Materii prime horticole mai importante pentru industria alimentară: struguri, fructe, legume. Edit. PIM Iași, Romania.

5. Biber PD (2007). Evaluating a chlorophyll content meter on three coastal wetland plant species. J. of Agricultural Food and Environmental Sciences. 1(2): 1-11. 
6. Boyer JS, Wong SC and G.D. Farquhar (1997). $\mathrm{CO}_{2}$ and water vapor exchange across leaf cuticle (epidermis) at various water potentials. Plant Physiology. 114: 185-191

7. Burzo I, Dejeu L, Şerdinescu A and Bădulescu L (2005). Fiziologia plantelor de cultură. Vol. III. Fiziologia viţei de vie. Edit. Elisavaros, București.

8. Callejas R., Kania E, Contreras A, Peppi C and Morales L (2013). Evaluation of a non-destructive method to estimate the concentration of chlorophyll in leaves of table grape cv. Idesia (Chile). 31(4): 19-26.

9. Cotea DV, Barbu N, Grigorescu C and Cotea VV (2000). Podgoriile și vinurile României. Editura Academiei, București.

10. Coţovanu Filimon R, Rotaru L, Căuleț R and Filimon VR (2012). Variation of photosynthetic pigments content under the influence of treatments with biostimulating substances at some table grape varieties grown in Iassy vineyard area. Scientific Papers U.A.S.V.M. Iaşi, Serie Horticulture. 55(1): 309-314.

11. Cuttriss A. and Pogson B (2004). Carotenoids. In Plant pigments and their manipulation. Vol. 14 (ed. Davies K. M.). CRC Press, Boca Raton, Florida, USA, pp. 57-92.

12. Davies KM (2004). Plant pigments and their manipulation. Annual plant reviews. Vol. 14, CRC Press, Boca Raton, Florida, USA, pp. 1-23.

13. Gandia S, Fernández G, García JC and Moreno J (2004) Retrieval of vegetation biophysical variables from Chris/ Proba data in the sparc campaing. Proc. of the $2^{\text {nd }}$ CHRIS/ Proba Workshop, ESA/ESRIN, Frascati, Italy. http://earth esa.int/workshops/chris_proba_04/papers/12_ Gandia. pdf.

14. Ghasemi M, Arzani K, Yadollahi A, Ghasemi S and Sarikhani SK (2011). Estimate of leaf chlorophyll and nitrogen content in asian pear (Pyrus serotina Rehd.) by CCM-200. Notulae Scientia Biologicae. 3(1): 91-94.

15. Gross J (1991). Pigments in Vegetables: Chlorophylls and Carotenoids. Van Nostrand Reinhold, New York.

16. Hopkins WG and Hüner PAN (2009). Introduction to Plant Physiology. John Wiley \& Sons, Inc., USA.

17. Jiang CD, Gao HY, Zou Q, Jiang GM and Li LH (2005). Enhanced photoprotection at the early stages of leaf expansion in field-grown soybean plants. Plant Sci. 168: 911-919.

18. Jiang CD, Shi L, Gao HY, Schansker G, Tóth SZ and Strasser RJ (2006). Development of photosystems 2 and 1 during leaf growth in grapevine seedlings probed by chlorophyll a fluorescence transient and $820 \mathrm{~nm}$ transmission in vivo. Photosynth. 44(3): 454-463.

19. Keller M (2010). The science of grapevines: anatomy and physiology. Academic Press, Elsevier Inc.

20. Khaleghi E, Arzani K, Moallemi N and Barzegar M (2012). Evaluation of chlorophyll content and chlorophyll fluorescence parameters and relationships between chlorophyll a, b and chlorophyll content index under water stress in Olea europaea cv. Dezful. World Academy of Science, Engineering and Technology. 6: 2112-2115.

21. Lebon G, Brun O, Magné C and Clément C (2005). Photosynthesis of the grapevine (Vitis vinifera) inflores- cence. Tree Physiology. Heron Publishing-Victoria, Canada. 25: 633-639.

22. Lee JH and Schwartz SJ (2005). Analysis of Carotenoids and Chlorophylls in Foods. In Methods of Analysis of Food Components and Additives (ed. Ötles S.). CRC Press, Taylor \& Francis Group, Boca Raton, FL. pp. 179-198.

23. Lichtenhaler HK (1987). Chlorophylls and carotenoids: pigments of photosynthetic membranes. Methods Enzymol. 148: 350-382.

24. Lichtenthaler HK and Wellburn AR (1983). Determinations of total carotenoids and chlorophylls a and $b$ of leaf extracts in different solvents. Bioch. Society Transactions. 11: 591-592.

25. Lichtenthaler HK, Kuhn G, Prenzel U, Buschmann C and Meier D (1982). Adaptation of chloroplast-ultrastructure and of chlorophyllprotein levels to high-light and lowlight growth conditions. Z. Naturforsch. 37(c): 464-475.

26. Lichtenthaler HK and Buschmann C (2001). Chlorophylls and Carotenoids: Measurement and Characterization by UV-VIS Spectroscopy. In Current Protocols in Food Analytical Chemistry (ed. Wrolstad R.E.). John Wiley \& Sons, Inc., F4.3.1-F4.3.8.

27. Lovisolo C, Schubert A and Restagno M (1996). Photosynthesis of grapevine leaves of different age at high and low light intensity. ISHS Acta Hort. 427: 91-93.

28. Maltini E, Torreggiani D, Venir E, Bertolo G (2003). Water activity and the preservation of plant foods. Food Chemistry. 82: 79-86.

29. Mendes-Pinto MM, Ferreira ACS, Caris-Veyrat C and De Pinho GP (2005). Carotenoids, Chlorophyll, and Chlorophyll-Derived Compounds in Grapes and Port Wines. J. Agric. Food Chem. 53: 10034-10041.

30. Mustea M (2004). Viticultură. Bazele biologice, înființarea și întreținerea plantațiilor tinere de vii roditoare. Edit. „Ion Ionescu de la Brad”, Iași.

31. Pfander H (1992). Carotenoids: an overview. Meth. Enzymol. 213: 3-13.

32. Richardson AD, Duigan SP and Berlyn GP (2002). An evaluation of noninvasive methods to estimate foliar chlorophyll content. New Phytologist. 153: 185-194.

33. Rotaru L and Târdea C (2002). Folosirea analizei cluster în ampelografie pentru stabilirea asemănărilor fenotipce la soiurile de viță de vie. Scientific Papers U.A.S.V.M. Iași, Serie Horticulture. 45(1): 189-193.

34. Rotaru L, Stoleru V, Filipov F, Mustea M and Petrea G (2011). The influence of the "Terroir" Concerning the Quantity and Quality of Grapes Yield at White Grapevine Varieties Growing in the Iasi Vineyard. Jornal of Life Sciences. 5(8): 646-653.

35. Schaper H and Chacko EK (1991). Relation between extractable chlorophyll and portable chlorophyll meter readings in leaves of eight tropical and subtropical fruittree species. J. of Plant Physiology. 138(6): 674-677.

36. Teodorescu Ș, Popa AI and Sandu GN (1987). Oenoclimatul României: Vinurile Româ niei ș i climatul lor caracteristic. Ed. Științifică și Enciclopedică, Bucharest, Romania.

37. Toma LD and Jităreanu D (2007). Fiziologie vegetală. Edit. "Ion Ionescu de la Brad", Iaşi, Romania. 
38. Van den Berg AK and Perkins TD (2004). Evaluation of a portable chlorophyll meter to estimate chlorophyll and nitrogen contents in sugar maple (Acer saccharum Marsh.) leaves. Forest Ecology and Management. 200: 113-117.

39. Willows RD (2004). Chlorophylls. In Plant pigments and their manipulation. Annual plant reviews. Vol. 14 (ed. Davies K. M.). CRC Press, Boca Raton, Florida, USA, pp. 23-57.

40. Yamamoto A, Nakamura T, Adu-Gyamfi JJ and Saigusa M (2002). Relationship between chlorophyll con- tent in leaves of Sorghum and Pigeonpea determined by extraction method and by chlorophyll meter (SPAD-502). J. of Plant Nutrition. 25(10): 2295-2301.

41. Young A and Britton G (1993). Carotenoids in photosynthesis. Springer Science Business Media Dordrecht. Published by Chapman \& HalI.

42. *** (2011). Spectranomics Protocol: Chlorophylls and Carotenoids. Carnegie Institution for Science 260 Panama Street, Stanford, USA. http://spectranomics.stanford. edu/technical_information. attachment/105. 